\title{
Mathematical models applied to the optimisation of mixtures in the production of silage from coffee by-products ${ }^{1}$
}

\author{
Modelagem matemática aplicada à otimização de misturas na produção de silagem \\ com subprodutos do café
}

\author{
Marcelo Ribeiro Malta ${ }^{2 *}$, Marcelo Ângelo Cirillo ${ }^{3}$, Larissa de Oliveira Fassio ${ }^{4}$, Adauto Ferreira Barcelos ${ }^{2}$ \\ and Priscilla Magalhães de Lima ${ }^{4}$
}

\begin{abstract}
The aim of this work was to propose a mathematical model to determine the best combination of the byproducts of coffee processing in the production of silage. To this end, 13 treatments were evaluated, resulting from the combination of wet coffee husks (WCH) and dried coffee husks ( $\mathrm{DCH})$, both with and without the use of molasses (M) and with or without the use of the inoculant Lactobacillus plantarum (I). From these components, various mixtures were proposed and evaluated, using the technique of simultaneous optimisation of multiple response variables. Silages with the best characteristics were obtained from the use of $76.40 \% \mathrm{WCH}, 18.77 \% \mathrm{DCH}, 4.83 \%$ of $\mathrm{M}$ and $0.0001 \% \mathrm{I}$.
\end{abstract}

Key words: Animal feed. Chemical composition. Mixture modelling. Component optimisation.

\begin{abstract}
RESUMO - Este trabalho teve como objetivo propor uma modelagem matemática para determinar qual a melhor combinação formada por subprodutos do processamento do café para a produção de silagem. Para atingir este objetivo foram avaliados 13 tratamentos, resultantes da combinação da casca de café úmida (CCU), casca de café seca (CCS), com ou sem a utilização de melaço (M) e com ou sem a utilização do inoculante Lactobacillus plantarum (I). Em função desses componentes, diversas misturas foram propostas, as quais foram avaliadas por meio da técnica de otimização de respostas simultâneas. As silagens com as melhores características foram obtidas com a utilização de 76,40\% de CCU, $18,77 \%$ de CCS, $4,83 \%$ de $\mathrm{M}$ e $0,0001 \%$ de I.
\end{abstract}

Palavras-chave: Alimentação animal. Composição química. Modelagem de misturas. Otimização de componentes.

\footnotetext{
DOI: $10.5935 / 1806-6690.20170045$

*Autor correspondência

Recebido para publicação em 08/09/2015; aprovado em 09/08/2016

${ }^{1}$ Resultado de projeto financiado pela Fundação de Amparo à Pesquisa do Estado de Minas Gerais/FAPEMIG

2Empresa de Pesquisa Agropecuária de Minas Gerais/EPAMIG, Caixa Postal 176, Lavras-MG, Brasil, 37.200-000, marcelomalta@epamig.ufla.br, adauto.barcelos@epamig.br

${ }^{3}$ Departamento de Ciências Exatas, Universidade Federal de Lavras/UFLA, Lavras-MG, Brasil, 37.200-000, macufla@gmail.com

${ }^{4}$ Departamento de Ciência dos Alimentos, Universidade Federal de Lavras/UFLA, Lavras-MG, Brasil, 37.200-000, larissafassio@yahoo.com.br, priscillamagalhaes.lima@gmail.com
} 


\section{INTRODUCTION}

Several alternatives have been proposed in the search for foods to complement cattle feeding during the dry season in much of Brazil, such as the use of by-products from agribusiness (COSTA et al., 2014; TEIXEIRA et al., 2007).

For Silva et al. (2006), the need to use agroindustrial residue that may be added to animal feed, being converted into protein of high biological value, has prompted a search for alternatives offering a greater integration of agriculture with livestock, and reducing production costs and impacts on the environment. On this basis, and according to several authors, the use of coffee husks, the residue from processing the coffee grain, shows great potential in the feeding of ruminants (BARCELOS et al., 2014; OLIVEIRA et al., 2007; PIRES et al., 2009).

These studies have shown that whole coffee husks and pulp can be used as feed for ruminants. However, some authors point out adverse factors, such as the presence of anti-nutritional aspects, low digestibility and low use efficiency by the animals of the nutrients contained in the husk and pulp; these have been seen as limiting factors in the use of the raw materials (MALTA et al., 2013; SOUZA et al., 2006).

Given the above, it would seem appropriate to carry out an optimisation study that could provide the maximum of responses, in order to use such by-products more efficiently in animal feed. For this purpose, the use of mixed-component models has been used in the formulation of dietary supplements (BRIGHENTI et al., 2010). According to Tedeschi et al. (2005), mathematical models in ruminant nutrition can be used to integrate knowledge related to feed, intake and rates of passage and digestion, with that of energy values of the feed and microbial growth efficiency. These authors note that the models can be valuable tools for estimating animal requirements and the nutrients derived from feeds that are present under specific conditions within a production system, thereby playing an important role in providing information that can be used in the decision-making process for improving production efficiency.

The aim of this study therefore, was to propose a mathematical model to determine the best combination of the by-products of coffee processing in the production of silage.

\section{MATERIAL AND METHODS}

The experiment and analyses were carried out at the Agricultural Research Company of Minas Gerais/Epamig in the city of Lavras, in the State of Minas Gerais. The husks used were from the coffee cultivar Mundo Novo, processed by both the wet and dry methods to obtain the wet and dry coffee husks respectively.

The treatments comprised wet coffee husks $(\mathrm{WCH})$, which originated from the husking of the mature coffee fruit with no drying, i.e. the fresh fruit; dry coffee husks (DCH) - obtained from processing the coffee in coconut; with $5 \%$ molasses (M) or with no molasses; and with the inoculant Lactobacillus plantarum (I) at $0.0001 \%$ and with no inoculant. Application of the inoculant followed the manufacturer's recommendations.

The experiment was carried out in a completely randomised design with 13 treatments and 3 replications. The formulations under evaluation for composition of the silage are described in Table 1, and are based on mixtures of various proportions of each component, with each mixture considered as one treatment.

Once the treatments had been prepared, they were placed into silo prototypes made from PVC, $250 \mathrm{~mm}$ in diameter and $750 \mathrm{~mm}$ high, and kept for a period of 60 days in a shed, protected from light. After this period, the silos were opened, and the complete contents removed and placed onto canvas to be homogenised. Samples were collected, placed into paper bags and kept in a greenhouse for 72 hours for drying at $60{ }^{\circ} \mathrm{C}$. The samples were then ground in a Wiley knife mill with a $1 \mathrm{~mm}$ mesh sieve. The silages were analysed for dry matter (DM), crude protein (CP) and ether extract (EE) content, and in vitro dry matter digestibility (IVDMD), as per Silva and Queiroz (2006).

The statistical model used to determine the silage was formed by the proportion of inoculant (I), molasses (M), dried coffee husks (DCH) and wet coffee husks $(\mathrm{WCH})$, in different respective concentrations, represented by $x_{i}(j=1, \ldots, q=4)$. As fractions are used to indicate the composition of each mixture, the sum of the components should be equal to one (1) (NEPOMUCENA et al., 2013).

$$
\mathrm{X}_{j} \geq 0 ; 1 \leq \mathrm{j} \leq \mathrm{q} ; \sum_{\mathrm{j}=1}^{\mathrm{q}} \mathrm{X}_{\mathrm{j}}=1
$$

Maintaining this restriction, a cubic mixture model was adopted, adjusted canonically as per expression (2).

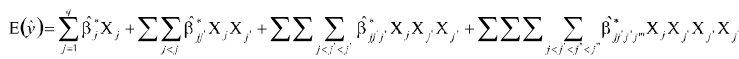

Each term corresponds to the $\mathrm{i}$-th component $\mathrm{x}_{\mathrm{j}}$ $(\mathrm{i}=1, \ldots, \mathrm{q}=4)$, representing the proportion of inoculant $(\mathrm{I})$, molasses (M), dry coffee husks (DCH) and wet coffee husks $(\mathrm{WCH})$ in different concentrations, given by $\mathrm{x}_{\mathrm{i}}(\mathrm{i}=1, \ldots, \mathrm{q}=4)$. The interactions between each component are represented by the coefficients with indices j, j', j" and j"'. 
Table 1 - Treatments encoded by proportion of components: inoculant (I), molasses (M), dried coffee husks (DCH) and wet coffee husks (WCH), in different concentrations

\begin{tabular}{ccccc}
\hline Treatment & $\mathrm{I}$ & $\mathrm{M}$ & $\mathrm{DCH}$ & $\mathrm{WCH}$ \\
\hline variable $(\mathrm{j}=1, \ldots, 4)$ & $\mathrm{x}_{1}$ & $\mathrm{x}_{2}$ & $\mathrm{x}_{3}$ & $\mathrm{x}_{4}$ \\
\hline 1 & 0.000000 & 0.000000 & 0.000000 & 1.000000 \\
2 & 0.000000 & 0.000000 & 0.100000 & 0.900000 \\
3 & 0.000000 & 0.000000 & 0.200000 & 0.800000 \\
4 & 0.000000 & 0.000000 & 0.400000 & 0.600000 \\
5 & 0.000000 & 0.050000 & 0.100000 & 0.850000 \\
6 & 0.000001 & 0.000000 & 0.100000 & 0.899999 \\
7 & 0.000000 & 0.050000 & 0.200000 & 0.750000 \\
8 & 0.000001 & 0.000000 & 0.200000 & 0.799999 \\
9 & 0.000000 & 0.050000 & 0.400000 & 0.550000 \\
10 & 0.000001 & 0.000000 & 0.400000 & 0.599999 \\
11 & 0.000001 & 0.050000 & 0.100000 & 0.849999 \\
12 & 0.000001 & 0.050000 & 0.200000 & 0.749999 \\
13 & 0.000001 & 0.050000 & 0.400000 & 0.549999 \\
\hline
\end{tabular}

After fitting the model, the lack of fit was estimated, so that, by comparing the probability (p-value) with the nominal level of significance set at $5 \%$, a non-significant result would justify selection of the cubic model for most variables. For model validation, the method proposed by Derringer and Suich (1980) was used, known as the simultaneous optimisation of multiple response variables, to include variables with different constraints and objectives, having regard for the experimental design and the adjusted model. To validate the optimal response, the desirability function (d) was considered.

In short, the aim of the function is to convert a problem with multiple responses into a single response using a process of normalisation. With this procedure, given $j=1, \ldots, q$ variables, interpretation of the desired function, represented by the index $d_{j}(j=1, \ldots, p)$ for each response variable, considers a range of 0 to 1 . The extremes, $d_{j}=0$, show that the researched optimal point can be interpreted as being completely undesirable; in the case of $d_{j}=1$, the optimal is considered as desirable or satisfactory.

Using an adjusted model, the behaviour of this function can be analysed, as described in (3).

$$
d_{j}=\left\{\begin{array}{lll}
0 & \text { for } & \hat{y}_{j}<y_{j L} \\
\frac{\hat{y}_{j}-y_{j L}}{y_{j T}-y_{j L}} & \text { for } & y_{j L}<\hat{y}_{j}<y_{j T} \\
\frac{y_{j U}-\hat{y}_{j}}{y_{j U}-y_{j T}} & \text { for } & y_{j T}<\hat{y}_{j}<y_{j U} \\
0 & \hat{y}_{j}>y_{j U}, \text { where },
\end{array}\right.
$$

$\hat{y}$ corresponds to the predicted value of the $\mathrm{j}$-th response; $\mathrm{y}_{\mathrm{jT}}$ indicates a specific value for the $\mathrm{j}$-th response of interest; $y_{\mathrm{jL}}$ indicates the lowest value that the desirable function may take, as long as $\left(\mathrm{y}_{\mathrm{jL}}\left\langle\mathrm{y}_{\mathrm{jT}}\right) ; \mathrm{y}_{\mathrm{jU}}\right.$ refers to the greatest value that the desirable function may take, providing $\left(\mathrm{y}_{\mathrm{jT}}<\mathrm{y}_{\mathrm{jU}}\right)$. Derringer and Suich (1980) proposed a global measurement, known as D, obtained as a joint estimate of the functions $d_{j}(j=1, \ldots, p)$ represented by the geometric mean (4), assuming the values for $\mathrm{p}$ to be variable.

$D=\left(\prod_{j=1}^{p} d_{j}\right)^{1 / p}$

This measurement is interpreted so that the higher the value for $\mathrm{D}$, the better the evidence that the stationary point obtained will be desirable to satisfy simultaneously the aims proposed for each variable. According to Rossi (2001) and Cirillo (2015), the closer D is to 1 the closer the original answers will be to their respective specification limits.

\section{RESULTS AND DISCUSSION}

Determination of the optimal combination between concentrations of the components of coffee by-products (Table 1) which would give an optimal response, and which would simultaneously maximize the variables dry matter (DM), ether extract (EE), crude protein (CP), and in 
vitro dry matter digestibility (IVDMD), was initially made considering a cubic model (2) adjusted for each variable, assuming the average response of three replications.

The probabilities of significance, obtained with the lack of fit test and the regression model, confirmed statistically that the proposed model was suitable for explaining the relationship between the independent variables (Table 1) and the experimental responses, with the exception of the variable EE (p-value<0.05). However, due to the fact that for all variables the adjusted model displayed high predictive power, confirmed by the coefficient of determination $\mathrm{R}^{2}(\%)$ (Table 2), and that it is not feasible to adjust the higher order models as a function of the number of experimental points used in the design, the cubic model was taken as the reference to be used in the optimisation procedure, following the methodology described above.

Due to the statistical basis of the estimates for validating the use of the cubic model, the method of simultaneous responses was applied, in which the specification limits (Table 3) are represented by the maximum and minimum responses obtained with each variable. Therefore, using as a reference interpretation of the global measurement D (4), in which the fit of the desirability function $\mathrm{d}$ is considered (3), the results obtained made it possible to validate the goodness of fit of the method of simultaneous optimisation of multiple responses in relation to obtaining the components that maximize the responses of the variables listed in Table 3.

The results presented in Table 3 show excellent indices that validate maximisation of the individual responses for the variables EE and IVDMD. However, as the fit of global D is close to 1 and the model is adequate for this variable, all the variables can be considered using global optimisation (Table 3). Accordingly, the concentrations obtained, which simultaneously maximise the relevant variables for improving silage quality, are described in Table 4. The silages with the best characteristics with respect to DM, CP, EE and IVDMD are obtained using $76.40 \%$ wet coffee husks, $18.77 \%$ dry coffee husks, $4.83 \%$ molasses and addition of the inoculant Lactobacillus plantarum at $0.0001 \%$.

The production of silage from raw materials with high levels of moisture can introduce losses to the various stages of the process (BERNARDINO et al., 2005). According to McDonald et al. (1991), silages produced from raw materials with a low dry-matter content can facilitate the development of bacteria of the genus Clostridium that produce butyric acid, causing degradation of protein and lactic acid. Furthermore, according to those authors, the formation of butyric acid results in large losses of dry matter, due to the production of $\mathrm{CO}_{2} \mathrm{H}_{2} \mathrm{O}$ and energy. Therefore, a reduction in moisture, whether by such techniques as wilting or the inclusion of absorbent

Table 2 - Results of the goodness of fit of the cubic model for the variables $\mathrm{DM}^{1}, \mathrm{EE}^{2}, \mathrm{CP}^{3}$ and $\mathrm{IVDMD}^{4}$

\begin{tabular}{|c|c|c|c|}
\hline Variable & $\mathrm{R}^{2}(\%)$ & Lack of fit (p-value) & Regression (p-value) \\
\hline $\mathrm{DM}$ & 96.11 & 0.762 & 0.037 \\
\hline $\mathrm{EE}$ & 86.88 & 0.000 & 0.000 \\
\hline $\mathrm{CP}$ & 84.70 & 0.067 & 0.019 \\
\hline IVDMD & 76.98 & 0.408 & 0.002 \\
\hline
\end{tabular}

${ }^{1} \mathrm{DM}$ : dry matter; ${ }^{2} \mathrm{EE}$ : ether extract; ${ }^{3} \mathrm{CP}$ : crude protein; ${ }^{4} \mathrm{IVDMD}$ : in vitro dry matter digestibility

Table 3 - Specification limits used in the method of simultaneous responses for maximisation of the responses of the variables DM ${ }^{1}$, $\mathrm{EE}^{2}, \mathrm{CP}^{3}$ and $\mathrm{IDVMD}^{4}$ and indices for goodness of fit given by the mean values for the individual (d) and Global D measurements of desirability

\begin{tabular}{|c|c|c|c|}
\hline Variable & Lower Limit & Upper Limit & Desirability (d) \\
\hline DM & 15.17 & 48.6 & 0.431 \\
\hline $\mathrm{EE}$ & 1.15 & 2.8 & 0.864 \\
\hline $\mathrm{CP}$ & 8.05 & 11.9 & 0.479 \\
\hline IDVMD & 33.38 & 59.6 & 0.702 \\
\hline Disirability $\mathrm{D}=0.600$ & & & \\
\hline
\end{tabular}

${ }^{1} \mathrm{DM}$ : dry matter; ${ }^{2} \mathrm{EE}$ : ether extract; ${ }^{3} \mathrm{CP}$ : crude protein; ${ }^{4} \mathrm{IVDMD}$ : in vitro dry matter digestibility 
Table 4 - Proportion of components resulting from the simultaneous optimisation of responses for $\mathrm{DM}^{1}, \mathrm{EE}^{2}, \mathrm{CP}^{3}$ and $\mathrm{IVDMD}^{4}$

\begin{tabular}{lcc}
\hline \multicolumn{1}{c}{ Component } & Predicted maximum response & Concentration $(\%)$ \\
\hline Inoculant & 29.59 & 0.000001 \\
Molasses & 2.57 & 0.048300 \\
Dry coffee husks & 9.89 & 0.187700 \\
Wet coffee husks & 51.88 & 0.764000 \\
\hline
\end{tabular}

${ }^{1} \mathrm{DM}$ : dry matter; ${ }^{2} \mathrm{EE}$ : ether extract; ${ }^{3} \mathrm{CP}$ : crude protein; ${ }^{4} \mathrm{IVDMD}$ : in vitro dry matter digestibility

additives, is necessary in the silaging of material with high levels of moisture such as the wet coffee husks used in this experiment, which had an average moisture content of $84.04 \%$. Dry coffee husks (DCH) were therefore added to the wet husks $(\mathrm{WCH})$ in order to increase the dry matter content of the silage. The dry coffee husks, residue from processing the coffee after drying, can act as an adsorbent additive, due to its high dry-matter content and hygroscopic properties (FARIA et al., 2010).

A positive effect on the attributes evaluated in the silage is also found from the addition of molasses. For Bernardino et al. (2005), the increase in carbohydrates may contribute to the decrease in $\mathrm{pH}$ of the silages, as they act as substrates for lactic acid-producing bacteria.

The addition of the enzymatic inoculant Lactobacillus plantarum contributed to the desirable characteristics of the silage. According to Coan et al. (2005), biological additives, bacterial inoculants, are made up of lactic-acid bacteria with or without added enzymes (cellulases, amylases and hemicellulases). The basic operating principle of these products is to increase the availability of single sugars via enzymatic complex, giving the bacteria access to these sugars, thereby increasing the production of lactic acid and promoting a rapid drop in the $\mathrm{pH}$ of the silage.

Several studies have been characterised for evaluating the effect of inoculants on the fermentation of various forages, and most were found to favour a decline in $\mathrm{pH}$ and increases in the levels of lactic acid (BOLSEN et al., 1992). The efficiency of silage inoculants depends on the level of bacteria in the culture, the buffering capacity and the amount and quality of the microorganisms added to the culture. In experiments that followed the fermentation dynamics of silages inoculated with lactobacilli, there was a rapid increase in the number of these microorganisms, a high production of lactic acid, rapid decline in $\mathrm{pH}$ and the consumption of soluble carbohydrates (BOLSEN et al., 1992). Acceleration of the fermentation process and the rapid drop in $\mathrm{pH}$ are responsible for decreased deamination, restricting proteolysis (McDONALD et al., 1991).

\section{CONCLUSION}

Determination of the components that maximise responses using the method of simultaneous optimisation of multiple responses proved to be suitable, as it allowed different specification limits to be detailed in characterising the silage. As such, using the proposed design, the silages with the best characteristics were obtained with the use of $76.40 \%$ wet coffee husks, $18.77 \%$ dry coffee husks, $4.83 \%$ molasses and the addition of the inoculant Lactobacillus plantarum at $0.0001 \%$.

\section{ACKNOWLEDGEMENT}

The authors wish to thank Fapemig and CNPq for funding this research and awarding scholarships.

\section{REFERENCES}

BARCELOS, A. F. et al. Valor nutritivo e características de silagens de cana-de-açúcar com diferentes proporções de casca de café. Revista Eletrônica de Pesquisa Animal, v. 2, n. 4, p. 156-168, 2014.

BERNARDINO, F. S. et al. Produção e características do efluente e composição bromatológica da silagem de capimelefante contendo diferentes níveis de casca de café. Revista Brasileira de Zootecnia, v. 34, n. 6, p. 2185-2191, 2005.

BOLSEN, K. K. et al. Effect of silage additives on the microbial sucession and fermentation process of alfafa and corn silages. Journal of Dairy Science, v. 75, n. 11, p. 3066-3083, 1992.

BRIGHENTI, D. et al. Optimization of the components of an energetic diet for africanized bees through the modelling of mixtures. Journal of Apicultural Research, v. 49, p. 326-333, 2010.

CIRILLO, M. A. Otimização na experimentação: aplicações nas engenharias e ciências agrárias. Lavras: UFLA, 2015. $226 \mathrm{p}$.

COAN, R. M. et al. Inoculante enzimático-bacteriano, composição química e parâmetros fermentativos das silagens dos capins Tanzânia e Mombaça. Revista Brasileira de Zootecnia, v. 34, n. 2, p. 416-424, 2005. 
COSTA, F. M. J. et al. Silagem de grãos úmidos de milho de textura dura ou macia em dietas com polpa cítrica para vacas em lactação. Arquivos Brasileiros de Medicina Veterinária e Zootenia, v. 66, n. 1, p. 203-210, 2014.

DERRINGER, G.; SUICH, R. Simultaneous optimization of several response variables. Journal of Quality Technology, v. 12 , n. 4 , p. 214-219, 1980.

FARIA, D. J. G. et al. Produção e composição do efluente da silagem de capim-elefante com casca de café. Revista Brasileira de Zootecnia, v. 39, n. 3, p. 471-478, 2010.

MALTA, M. R. et al. Composição bromatológica e fatores antinutricionais de silagens produzidas com subprodutos do processamento do café. Revista Brasileira de Agropecuária Sustentável, v. 3, n. 2, p. 31-38, 2013.

McDOLNALD, P. et al. The biochemistry of silage. 2. ed. Marlow Bucks: Chalcombe Publications, 1991. 340 p.

NEPOMUCENA, T. M. et al. Modelos ridge em planejamento de misturas: uma aplicação na extração da polpa de pequi. Química Nova, v. 36, n. 1, p. 159-164, 2013.

OLIVEIRA, A. S. et al. Substituição do milho por casca de café ou de soja em dietas para vacas leiteiras: consumo, digestibilidade dos nutrientes, produção e composição do leite. Revista Brasileira de Zootecnia, v. 36, n. 4, p. 1172-1182, 2007.
PIRES, A. J. V. et al. Capim-elefante ensilado com casca de café, farelo de cacau ou farelo de mandioca. Revista Brasileira de Zootecnia, v. 38, n. 1, p. 34-39, 2009.

ROSSI, F. Blending response surface methodology and principal components analysis to match a target product. Food Quality and Preference, v. 12, p. 457-565, 2001.

SILVA, D. J.; QUEIROZ, A. C. Análise de Alimentos: métodos químicos e biológicos. 3. ed. Viçosa, MG: UFV, 2006. 235 p.

SILVA, M. E. T. et al. Degradação da matéria seca e da proteína bruta de silagens de milho sem espigas com cana-de-açúcar e bagaço de mandioca. Acta Scientiarum Animal Sciences, v. 28, n. 4, p. 423-429, 2006

SOUZA, A. L. et al. Casca de café em dietas para novilhas leiteiras: consumo, digestibilidade e desempenho. Revista Brasileira de Zootecnia, v. 35, n. 3, p. 921-927, 2006.

TEDESCHI, L. O. et al. Using mathematical models in ruminant nutrition. Scientia Agrícola, v. 62, p. 76-91, 2005.

TEIXEIRA, R. M. A. et al. Consumo, digestibilidade e desempenho de novilhas alimentadas com casca de café em substituição à silagem de milho. Revista Brasileira de Zootecnia, v. 36, n. 4, p. 968-977, 2007. 